NBER WORKING PAPER SERIES

\title{
SPURTS IN UNION GROWTH: DEFINING MOMENTS AND SOCIAL PROCESSES
}

Richard B. Freeman

Working Paper 6012

\section{NATIONAL BUREAU OF ECONOMIC RESEARCH 1050 Massachusetts Avenue Cambridge, MA 02138 \\ April 1997}

This paper is part of NBER's research program in Labor Studies. Any opinions expressed are those of the author and not those of the National Bureau of Economic Research.

(C) 1997 by Richard B. Freeman. All rights reserved. Short sections of text, not to exceed two paragraphs, may be quoted without explicit permission provided that full credit, including $(\mathcal{C}$ notice, is given to the source. 
Spurts in Union Growth: Defining Moments

and Social Processes

Richard B. Freeman

NBER Working Paper No. 6012

April 1997

Labor Studies

\begin{abstract}
This paper examines the spurt in U.S. unionism during the Great Depression. It argues that the Depression spurt is better understood as resulting from a Depression sparked endogenous social process than from New Deal legislation and Congress of Industrial Organizations (CIO) leadership. Four pieces of evidence are offered for this interpretation:

1. The ubiquity of spurts in unionization across countries, particularly in the Depression.

2. The widespread use of recognition strikes during the 1930 s spurt.

3. The growth of $\mathrm{CIO}$ affiliates with little CIO financial or organizing aid.

4. The growth of American Federation of Labor (AFL) affiliated unions.

I model unionization as the outcome from a conflict between union/worker organizing activity and employer opposition, both of which depend on the proportion organized. Union organizing and activity rises with density, then falls with density. Employer opposition is high at low densities but falls once unions gain control of the relevant market. The result is a nonlinear difference equation that produces spurts of union growth. The Depression initiated a spurt by increasing worker desires for unions and by raising density above the "critical level" for rapid growth in many industries.
\end{abstract}

Richard B. Freeman

Department of Economics

Harvard University

Cambridge, MA 02138

and NBER

freeman@nber.org 
The 1930s Depression growth of unionism is the most studied and discussed period in U.S. labor history. Many analysts view the thirties as a turning point in the development of the American labor relations system. Participation in unions exploded in the 1930s, with the sharpest increase in density occurring with the Supreme Court's decision upholding the National Labor Relations Act (Wagner Act) in 1937 (see Figure 1). The Wagner Act, modified by the Taft-Hartley Act (1947) and ensuing legislation, continues to provide the legal framework for establishing unions in the United States. The 1930s growth of unionism was also associated with the development of industrial unions and the formation of a new national grouping of unions, the Congress of Industrial Organizations (CIO). In explaining the successful unionization of the blue-collar work force in the 1930s, labor historians place great emphasis on the Wagner Act; the dramatic events surrounding the formation of the CIO; the development of the industrial union; and the specific battles and personalities of the era--John L. Lewis, Philip Murray, Walter Reuther, President Roosevelt, among others. It was an era of legends.

Was the Depression growth of U.S. unionism a unique event in trade union history or was it part-and-parcel of the normal pattern of union development? Is there an underlying social dynamic behind the growth in unionization? Did the 1930s leave an institutional legacy that makes this period a "defining moment" in the history of U.S. labor relations; and, if so, what is that legacy?

Because the expansion of unionism in a single country in a single period leaves much scope for interpretation and only limited possibility for testing interpretations (where do we find the appropriate counter factual to any given interpretation?), I consider the U.S. 
Depression-era experience in light of developments in other countries and in other time periods. I find that unionism generally grows in discontinuous spurts and that the period of the Great Depression was one of union growth in many countries. This leads me toward an explanation of the Depression experience in terms of a general theory of employer-employee conflict over organization as opposed to an explanation rooted in specific events and personalities in the Depression and United States. Specific events and persons ignite processes and potentially impel those processes in particular directions at formative times, but the key to understanding union growth lies in the endogenous social process, not in the historical detail, which vary from period to period and country to country. As to the legacy of the Depressionspurt, the 1960 s to 1990 s decline of private sector density to pre-Depression levels belies the view, prevalent twenty or thirty years ago, that the New Deal established a stable system of collective bargaining. The legacy of the Depression-era spurt is quite different: an institutional framework for establishing unions and collective bargaining that has become outmoded from the vantage point of workers, unions, and firms.

\section{Spurts of Unionism: The Quantitative Record}

Statistics on union membership for the United States and other countries show that trade union growth takes the form of discontinuous "spurts" rather than gradual logistic growth to some equilibrium value. The expansion of unionism in the Depression era was an exceptionally large spurt but one with parallels in U.S. history and in other countries as well. 


\section{The American Experience}

Figure 1 shows the pattern of union density in the U.S. from 1880 through 1995 . For most of the period, unions were concentrated in the private sector, so the density figures largely represent that sector. In the 1960s, however, public-sector unionism grew substantially, but the overall pattern is still dominated by developments in the private sector. "Optimetrics" Shows five spurts in union density: 1880 to 1886,1897 to 1904 ; 1916 to $1921 ; 1934$ to 1939 ; and 1942 to 1945 . Whether we should divide the Depression-era growth of unionism into the 1934 to 1939 and 1942 to 1945 spurts is questionable. The Bureau of Labor Statistics series on union membership, on which I rely, shows a break, but the series of union membership reported by Troy and Sheflin (1985) does not. Commons, et al. (1918), Dunlop (1948), and most analysts differentiate between the two periods, and I shall do so also. In addition, there is a spurt in public-sector unionism from about 1962 to 1972 or so.

Going beyond the visual picture, the notion and treatment of "spurts" in union growth can be developed further. By a spurt I mean a sharp concentrated episode of union growth. In such an episode, membership should grow more rapidly in a few contiguous years than would be expected by any model of random fluctuations in growth, even with some auto-correlation in the rate of growth. In addition, for spurts to be a growth phenomenon, the pattern of increases in union density should differ from the pattern of decreases in union density during periods of decline.

The statistical measures of changes in U.S. union density in private sector spurts and in "non-spurt" periods shown in Table 1 indicate that the designated periods meet these criterion. 
The change in density is larger in the spurt periods (an average annual gain of 2.2 percentage points) than in the non-spurt periods when density increased (an average annual gain of 0.5 percentage points) or than in non-spurt periods when density declined (an average annual loss of 0.8$)$. The change is also highly concentrated: gains in union density are more likely to be clumped together than decreases in density and are more highly correlated than are declines in density. The "optimetrics" reading of the data is not spurious: spurts in growth are real. By contrast, absent the periods of spurt, U.S. union history is characterized by gradual erosion of union density.

How does the 1934 to 1939 Depression-spurt look in this context? It had the largest growth of density and of density per year of any spurt. In contrast to the other spurts, it occurred in a peacetime period of high unemployment. It was associated with innovations in labor laws and in the nature of union organizations that created a "new unionism" in the form of industrial unions. Earlier spurts were associated with either substantive legal changes (during World Wars I and II the government encouraged settlement of disputes) or new forms of unionism (the 1897 to 1904 spurt was related to the formation of the AFL; the increase in unionism in the 1880s was due in large part to the growth of the Knights of Labor), but not with both. Finally, the 1934 to 1939 spurt was followed by the 1942 to 1945 spurt associated with World War II. This arguably brought union strength to levels that would never have been achieved or maintained simply from the 1930s spurt. In fact, between 1939 and 1942 union density fell (though membership increased), suggesting that at least some of the 1930s gain in density would have eroded absent World War II. 
There are two possible ways in which aggregate unionism can increase rapidly in a spurt. Existing unions with given jurisdictions could greatly increase their representation. The Carpenters' Union might, for example, successfully organize carpenters in nonunion areas. Alternatively, new or existing unions could expand into previously non-union sectors. Extant data on unionization by industry are limited before the 1950s, but figures on membership for particular unions provide a disaggregated picture of the spurt process by organization. Before the Depression expansion, most unions were organized on a craft basis, with explicit jurisdictions; and the pre-CIO industrial unions, such as the Miners', also had relatively narrow jurisdictions. Thus, expansion of existing unions would indicate organization of sectors where unions were traditionally concentrated. Creation of new unions would indicate union growth in traditionally nonunion occupations or industries.. Using data from Troy and Sheflin (1985), I have examined the growth of individual unions in the four spurts identified in Figure 1 and Table 1, and in the relevant non-spurt periods. The results of this analysis are summarized in Table 2. Because I do not have information on employment within each union's jurisdiction, I report the growth in terms of percentage changes in absolute membership. While this overstates growth in union density in relevant jurisdictions in periods of economic upswing, the rates of change in union membership during the various spurts are so great that they invariably imply large changes in density. The table shows, in any case, that in a spurt nearly every union experiences membership gains.

However, in the 1930s, a larger proportion of the growth took the form of the formation of new unions than in previous spurts. This helps explain the greater magnitude of that spurt than of previous spurts. The ubiquity of growth among existing unions and the 
formation of new unions in the Depression era suggests a "sea change" in labor-management relations that made this spurt something different. In fact, it is this sea change in the labor market that labor historians have stressed in their descriptions of the period (Bernstein 1971; Galenson 1960)

Finally, note that the spurt not covered in the table, involving public sector workers in 1962 to 1972, has similar properties to the spurts shown in Table 2: rapid expansion of unionism in new areas with new or changed organizations (the switch of employee associations such as the National Education Association (NEA) into unions) and growth of existing unions under the aegis of legal changes (Freeman 1986).

\section{Experience of other countries}

Are spurts in union growth unique to the United States or do they characterize other countries as well? Given the historically confrontational labor relations of the United States, we might expect to see less jumpy patterns of union growth in other countries. In some countries, union growth has in fact been less discontinuous than in the United States, but in most advanced capitalist countries we find a pattern similar to the U.S. experience: union growth taking the form of sharp concentrated spurts in membership. Even more striking, union growth spurts have occurred in roughly similar periods in most countries. For instance, union density rose sharply in the United States, United Kingdom, Germany, Sweden, Denmark, Norway, and Australia around the early 1900s. Density also grew during the World War I period in all countries for which data exist. 
Table 3 provides a rough picture of the time pattern of the growth or decline of union density across countries that highlights the similarity in the timing of spurts. The number of countries in the table differs from period to period due to differing availability of union membership data. There is information on 7 countries in the 1900s, 6 countries in 1910-1916, 12 countries until the mid 1930s-World War II period when Germany and Austria are excluded because of the Nazi suppression of free trade unions, and an increasing number of countries thereafter. The most striking pattern in the data is the similarity in most periods in union growth across countries that enables me to label the periods as times of spurt, stability, or decline. Union membership spurts in all of the countries for which I have data in the 1900s, in World War I, and in the mid-1930s/World War II period. For instance, in the United Kingdom, density jumped from 1910 to 1913 (15 percent to 23 percent); from 1916 to 1920 (26 percent to 45 percent), from 1939 to 1943 (32 percent to 40 percent), from 1945 to 1948 (39 percent to 45 percent). It grew in the majority of countries in the 1970 s, with the U.S. being an outstanding exception. In other periods, density was stable or falling. Declines in density occurred in nearly all of the countries in the 1920s and in a majority of countries in the 1980s to the mid-1990s. Density was stable in 1910-1916, and the 1950s and 1960s.

I have given broad time groupings in the table and have, in particular, compressed the mid-1930s-World War II period into one interval, because the Depression and war occurred in different times among the countries. The table is "stylized" because I have used differently sized time windows for the periods to summarize the pattern, but the mean change in density is a "hard" statistic: the unweighted average of changes in density for the countries in the part of the period when they had their spurt. 
Table 4 focuses on union density in the Depression to World War II period (with somewhat different years shown for the countries to capture the timing of their particular spurt). The table shows that union density rose prior to the war in several countries as well as in the United States, though in some cases the increase was less concentrated in a few years (the Depression experience of Denmark, in particular, is misleading as Danish density began trending up earlier). In the United Kingdom density jumped from 22.6 percent in 1933 to 33.1 percent in 1940; in France, density went from 7.0 percent in 1935 to 35 percent in 1937; in Norway density increased from 13 percent in 1927 to 43 percent in 1939, and so on. The similarity in the pattern suggests that unionization in the Depression did not reflect countryspecific political events but rather a more fundamental response of employees to the Depression situation.

In sum, I conclude that data on union density for the U.S. and other countries shows that unionism generally grows in sudden sharp spurts and that the Depression spurt of unionism in the U.S. is not an isolated country phenomenon, but rather exemplifies a general pattern in this seemingly inhospitable period for unionism. This regularity raises two questions about the growth of unionization. Is there is a single underlying social process for growth by spurts, and if so, what is that process? Why does union growth occur in roughly similar periods across countries, including the Depression when one might have expected unions to be particularly weak? The former question relates to the dynamics of growth. The latter relates to its timing. 


\section{Why Spurts?}

Two types of models can generate spurts in union growth. The first are models in which the process of growth creates non-linearities that produce "phase transitions" when certain conditions are met--models of tipping, contagion, self-organized complexity. The second are standard comparative statics linear models in which massive shocks or environmental changes generate commensurately large responses in otherwise stable union membership. The former models stress the underlying process by which organization occurs and the cumulative behavior of individual workers, unions, and firms. The focus is on the behavior of thousands or millions of individuals acting in response to one another. The latter models stress the exogenous shock, usually generated by political forces. Historians of unionism in particular countries generally interpret the growth of unionism in their country as resulting from political "top-down" changes: unions grew in the United States because of the Wagner Act; in France because of the Blum government in France; in Canada because of the enactment of PC 1003; and so on. Without denying the importance of particular laws or events as catalysts or triggers for the growth process, $I$ lay out in this section a model in which sudden sharp changes in union density--discontinuities--arise from the process of organization.

My model concentrates on two aspects of unionization: the conflict between management and labor in the formation of unions; and nonlinearities in the benefits/costs/strengths that accrue to the two sides from different levels of unionization. The model makes union formation an outcome of a battle between management and labor, rather than of the "laboratory voting" procedure the National Labor Relations Board (NLRB) 
envisages. Prior to the Wagner Act, organization was largely a matter of strategic workers using economic muscle to force employers to accept a union at their workplace (Dunlop 1948) per the battle motif. Absent the strike threat by workers to impose economic costs on firms, management might refuse to recognize a union even if virtually all workers supported it. The result was a large number of often bitter recognition strikes during many union spurts. A major goal of the Wagner Act was to transform this process into a secret ballot election campaign.

The model generates nonlinearity in organizing because the resources unions or employers bring to the campaign and the incentives that they have to use their resources to organize or oppose organization depend critically on the percentage organized or covered by collective bargaining in the relevant market. When union density is low, unions have little strength to organize new firms and firms have a large incentive to oppose organization. As union density rises, unions have increased resources to use for organizing and firms see less competitive disadvantage in being organized. Thus, at some range of union density, union organizing strength rises and employer opposition falls, potentially producing a spurt in membership.

The backbone of this model is an accounting identity for union density:

$$
\mathrm{UNION}_{\mathrm{t}}=(1-\mathrm{r}) \mathrm{UNION}_{\mathrm{t}-1}+\mathrm{NEW}_{\mathrm{t}}(1)
$$

where UNION = union density in a given product market in a particular year, defined as members/employment in that sector; $r$ is the "normal" rate of depreciation of that density due 
say, to attrition of members or firms or the growth of employment in new firms that have not yet been organized; and where $\mathrm{NEW}=$ the ratio of new members organized to employment in the given year.

I define UNION as union density in a product market because the model focuses on the effects of unionization on firms that compete in the same area, and on the ability of collective bargaining to create a "level playing field" in terms of a single wage/benefit/conditions package in that sector that can reduce initial employer opposition to unions.

The key to the model is the rate of new organization, which depends on the resources that labor and management devote to organizing or opposing organization:

$$
N E W=f(O R G, O P P)(2)
$$

where $O R G=$ the resources unions give to organizing; and OPP = resources management gives to opposing union drives.

The function $\mathrm{f}$ is the key element of the model. As written, it is a production function of sorts, with $\mathrm{df} / \mathrm{dORG}>0$ and $\mathrm{df} / \mathrm{dOPP}<0$. Beyond this, it is difficult to specify functional form. One possibility is that $\mathrm{f}$ has diminishing marginal productivity in both ORG and OPP, so that, conditional on employer opposition, more organizing effort will yield diminished growth of membership and conditional on organizing effort, employer opposition will also have diminishing returns. But it is also possible that ORG or OPP have increasing marginal productivities over some range: a massive union drive might pay off much more than a smaller 
drive; employer opposition around a single banner--the American plan--might be more successful in defeating union organizing than efforts by individual employers.

To close the model requires equations for ORG and OPP. ORG presumably depends on existing union resources; the potential benefits to existing members from spending their dues money on organizing new members; the benefits to nonunion workers of unionization, and so on. One could readily imagine ORG resulting from some form of union optimizing behavior. What my model requires is that at very low levels of unionization, ORG will be small: the union simply does not have the resources to devote to organizing campaigns. I expect that ORG is also low at high levels of unionization: at high density the union will have effective control over the market for labor, and existing members will gain little from expanding membership. If union benefits spillover to nonunion workers through "threat effects", new workers may also gain little. For simplicity, I postulate that ORG rises, then falls more or less parabolically, with UNION. The OPP relation depends on firms' estimates of the benefits/costs of operating union or nonunion; their assessment of the likely success of efforts to defeat union organizing drives; and the resources they have to combat the union. OPP is likely to be high when UNION is low: if the union is too weak to establish a "level playing field" in a sector, firms who get organized risk suffering a competitive disadvantage by paying higher wages/benefits. OPP may or may not be high when UNION is high: a nonunion firm in a primarily union market may find that to maintain this status, it must operate by union rules and pay union or higher wages or spend considerable resources fighting off organizing drives, reducing the incentive to oppose union organizing efforts. On the other hand, if the firm can remain nonunion and avoid sharing economic rents with workers, it may be able to earn 
exceptionally high profits. As the analytics require only a single nonlinearity in the relation between union density and the resources devoted to the process of gaining new members, I assume for simplicity that employer opposition is simply a declining function of UNION.

The result is a nonlinear difference equation that readily generates sharp jumps in union density. ${ }^{1}$ Figure 2 captures the essential nonlinearity. In Part A of Figure 2 there are two stable union equilibria, 0 and $U^{*}$, and one unstable equilibrium, $U^{\prime}$. Union density grows whenever ORG exceeds OPP (more properly, when NEW $=f(O R G, O P P)>r$ UNION $\left._{-1}\right)$. In Part B of the figure, I assume that the initial unionization point is $\mathbf{0}$ (or some other low level). Beginning at 0, a gradual increase in the union-employee desire for organization, which shifts upward the ORG curve, or a gradual decrease in employer opposition to unionization, which shifts downward the OPP curve, have no effect on the union density until a critical point is reached: the point where $\mathrm{ORG}(0)>\mathrm{OPP}(0)$. In part $\mathrm{B}$ the increase in the organizing function to ORG* creates this situation. The result is a sudden spurt in density to the equilibrium U*.

As it stands, this model predicts both sudden spurts and sharp declines in union density. But in the United States (and many other countries), it is difficult to displace unions in workplaces where they exist. The Wagner Act made that particularly difficult by requiring a decertification process so that a firm could end a union relationship only when workers voted to decertify the union, though a firm with strong bargaining power could effectively eliminate unions by refusing to come to a collective bargaining agreement, and bringing in replacement workers to take the jobs of union members if the union struck. For the United States, though, I assume that shifts in ORG or OPP that reduce density do not have such a discontinuous effect and make the maximum loss of density in a given period $\mathrm{r} \mathrm{UNION}_{-1}$. Thus, the nonlinearity of 
the model transforms gradual changes in the underlying desire for or opposition to unionism into jumps to new equilibrium on the growth side but produces gradual drops in density on the decline side.

The point of this exercise is not to derive "the" union growth or decline equations applicable to all institutional settings or time periods but rather to highlight the potential for producing endogenous spurts when union and firms battle over organizing drives, given the likely relation between their allocation of resources to organizing or opposing activity and extant density. The key condition for growth spurts rather than gradual growth of unionization is confrontation over the union institution. The logic of the model suggests that in the early phase of a spurt there will be considerable conflict but that this conflict will diminish as the incentive for firms to oppose unions falls with higher levels of density; and that unionism will be concentrated in selected sectors as opposed to being evenly spread across sectors in the workforce. It makes product markets critical in analyzing union growth.

To go further, it is necessary to specify the factors likely to shift the ORG and OPP schedules over time in a particular setting. For the United States in the Depression period, these factors include the New Deal labor policies, notably the Wagner Act that most labor historians stress; the attitudes of workers, dependent on their assessment of the likely benefits and costs of unionization; the resources and incentives facing firms; and the resources and incentives of unions, including innovations in union structure, such as the formation of the CIO under John L. Lewis. The magnitude of the Depression and consequent loss of belief in business leadership offers a potentially strong candidate for raising worker desire for unionization, which in the framework given above shifts the ORG curve. In other time 
periods, such as the World War I or World War II spurts, economic booms might have reduced employer opposition, making unionization easier, even absent a change in ORG. For other countries, one may come up with a similar list of the incentives to governments, employees, and firms and unions that arguably shifted over time. Since institutions affect compensation and benefit packages, moreover, the same economic changes might alter the benefits and costs to different parties differently in different countries. For example, in a European country with extension of collective bargaining contracts (from the organized sector to nonunionized firms), the incentive of employers to oppose unions will be much less than in a country with plant or firm level bargaining. But the task of this paper is not to explain unionization around the world but to use that and other evidence to cast light on the most dramatic period of U.S. union history.

\section{The Depression and World War II Spurts in the United States}

The 1934 to 1939 Depression-spurt and the World War II spurt raised United States union density to unprecedented levels and seemed, through the 1960s at least, to make unions a permanent and accepted part of American society. In both spurts there was a substantial increase in density in private sector industries outside of the services, but little growth of density in the service sector or government (Table 5). The World War II spurt fits an overall pattern in which unionism grows in war periods (recall the growth throughout the advanced world in World War I), as governments seek to maximize production by minimizing labor disputes. Most labor experts would predict a growth of unionism in such a time period. But the 
Depression-era spurt came as a shock to the experts of its period. In 1932 George Harold Barnett, the President of the American Economic Association (AEA), and an expert in industrial relations, declared: "American trade unionism is slowly being limited in influence by changes which destroy the basis on which it is erected ... I see no reason to believe that American trade unionism will ... become in the next decade a more potent social influence" (1933). Perhaps in no other period of American history has the growth of unionism seemed so surprising.

There are two interpretations of the causes of the 1930s spurt in the United States, each focused on the possible catalytic role of particular social actors. The first interpretation, which I will call the top-down hypothesis, is that the 1930s growth resulted from the decisions of the Roosevelt Administration, the passage of pro-labor New Deal legislation, and the formation of the CIO by a group of innovative union leaders led by John L. Lewis. Many analysts adhere to the view that a sympathetic administration in Washington was necessary, and perhaps even sufficient, to spark the growth of unions. They place great weight on the enactment of the National Industrial Relations Act (NIRA) and the Wagner Act. Some have gone so far as to call this "the most radical piece of legislation ever enacted" (Klare 1978, p. 265). Bernstein declares that "American labor history took an eventful turn with the coming of the New Deal" (1971, p. ix) and devotes much of his prologue chapter to Roosevelt and his administration. Taft claimed that: "The change in the future of American labor which took place in 1933 was almost entirely due to the legislative measures ... of FDR" (1964, p. 416). Goldfield (1987) attributes similar views to many other analysts: Burns (1956), Derber and Young (1957), Schlesinger (1958), Leuchtenberg (1963), and Freidel (1973). The Act aside, when unions can 
declare that "the President wants you to join" (as in one CIO organizing poster) surely it had to matter somewhat. A variant of the top-down hypothesis is that the leadership provided by John L. Lewis in forming the CIO was also a critical component in growth . According to Taft "the CIO was largely the creation of John L. Lewis without whose leadership and financing the movement would have foundered and expired"(p. xx). Taft's story is basically that if you removed FDR and Lewis, nothing much would have happened on the union front in the Depression.

Interpretation two is quite different. It is that the catalyst for the 1930 s spurt was the grievances of employees and their loss of faith in business leadership. Government policies and union leadership were endogenous responses to the changed views of employees. Since the spark for union growth emanates from workers, I call this the bottom-up hypothesis. Horace Davis's theory of union growth exemplifies this view: "when labor has major grievances and an improving position in the labor market, unions tend to grow" (1941, p. 623 ). He argued that the grievance--loss of jobs or risk thereof--was exceptional in the Depression and that the direction of movement in the economy, rather than the level, was critical in allowing unions to develop. In this view unionism can grow in an economic recovery, even if the recovery is still associated with high joblessness. This hypothesis stresses the activities of workers, firms, and unions operating as individual agents, whose collective action determines unionization and influences governmental policy. Absent FDR and the Wagner Act and John L. Lewis, there still would have been substantial growth of unionization in the late 1930s, according to this hypothesis. 
There are problems in differentiating between these explanations. The 1930s spurt occurred during the New Deal, was accompanied by the CIO split, and occurred in a period of recovery from economic recession. One could legitimately argue that the spurt began when a weighted sum of contributing factors, $\sum w_{i} X_{i}$, exceeded some critical value, where $X_{i}$ measures one of the factors, and $w_{i}$ is its effect on unionization. In the Figure 2 diagram ORG - OPP would depend on this sum. In this case, the issue of deciding between the two interpretations is not one of accepting the top-down story or the bottom-up story, but of partitioning the weighted sum to determine which set of factors was more important. Such a calculation would presumably give some weight to all factors and thus lead to a multi-causal explanation of the spurt that would not reject either hypothesis. But the counter factual for determining what would happen absent the observed $X$ should not be a simple ceteris paribus thought experiment in which one removes $X$ and holds everything else the same. Rather, the counter factual requires a more complex thought experiment that assesses how the remaining factors might adjust to the change. Perhaps absent one factor, other causal factors would have increased sufficiently to keep the weighted sum above the critical value. In the case of the 1930 s Depression-spurt, had Congress failed to enact the Wagner Act, might unions have expanded more through traditional recognition strikes? Absent John L. Lewis and the CIO, would AFL unions have eventually responded to the opportunities afforded by worker discontent in mass production industries, or might some other entrepreneurial union leader have stepped forward to take greater initiative than the AFL had shown up to that point? Or might another form of worker organization have come forth to unionize the mass production industries? 
To assess the top-down and bottom-up interpretations of the Depression-era spurt, I have examined three aspects of the unionization drive of the period: the extent to which unions formed through NLRB elections versus the recognition strikes the legislation was designed to supplant; the extent to which the new CIO unions were in fact aided by the federation; and the extent to which the old AFL unions responded to the new situation. If the top-down analysis is correct, I would expect: that recognition strikes would not continue to be a major mode of unionization once the benefits of the secret ballot process was established; that the bulk of the new unions in the CIO would have relied on central funds or organizing assistance; and that the AFL unions, which lacked the dynamic leadership of Lewis, and which were less favored by the New Deal than the CIO, would gain fewer members than the CIO unions.

Data relating to all three of these "tests" reject the top-down hypothesis in favor of an explanation of the Depression-era spurt that places greater weight on the independent activities of workers/local unions in a bottom-up organizing effort. From this perspective the Wagner Act was less an exogenous change in regime that caused the union spurt and more an endogenous outcome of unionizing pressures--a government means for channelling worker desires for unionism and employer opposition into a less violent and confrontational mode for determining organization and collective bargaining arrangements. This does not mean that the Act had no effect on the events of the period, but that absent the Act or in the presence of, say, a weaker labor law, there still would have been a major union spurt in the Depression period.

Consider first the evidence on recognition strikes. Despite the creation of the NLRB and "laboratory" elections for workers to choose whether or not they wanted to unionize, a 
huge number of workers were organized in the 1930 s and through the war years by recognition strikes. In 1934, when Roosevelt ordered the Labor Board to conduct bargaining elections, there were 552 recognition strikes involving over 700,000 workers. Table 6 shows that the number of workers involved in recognition strikes varied in ensuing years, trending downward as the National Labor Relations Act procedures become increasingly accepted, but still remaining high as late as 1937, when the Supreme Court declared the Wagner Act constitutional. $^{2}$ More surprising is the fact that recognition strikes were also an important method of organizing in 1941,1944, and 1945. Overall, more workers were organized through recognition strikes in the 1934-1939 spurt than were organized through NLRB elections: 1.8 million through recognition strikes vs 1.0 million via NLRB elections. This suggests that the Act may have changed the nature or process of union organization after 1937 more than it changed the actual number organized. A legitimate interpretation of the data is that the election procedure largely substituted for recognition strikes that would have created a comparable growth of unionism in a more confrontational way. If this is the case, the claim that the Depression-based spurt was bottom up driven rather than top-down driven is enhanced. How many workers might have successfully unionized through 1939 in the absence of an election procedure? A minimal estimate would be the number who in fact organized through recognition strikes: the 1.8 million workers organized through recognition strikes is $33 \%$ of the 1934-39 growth in union membership of 5.5 million reported in Appendix table A. Many workers, of course, joined existing unions so that membership rose absent either strikes or NLRB elections. If this growth was simply proportionate to the growth of non-agricultural employment, membership would have risen by $18 \%$ from 1934 to 1939 , or 900,000 persons. I 
will not try to predict how many persons would have joined unions from the 1937 to 1945 period absent the Wagner Act, but simply note that the growth in the latter period was comparable to that in World War I, with no New Deal legislation.

Consider next the evidence on the growth of $\mathrm{CIO}$ unions. How much of $\mathrm{CIO}$ membership growth resulted largely from the activities of workers and autonomous unions and how much from top-down central CIO assistance?

Two of the most important organizing drives in the 1930s and 1940s were in automobiles and steel, both highly oligopolized sectors with a large dominant firm whose unionization virtually guaranteed success in the sector. The automobile workers, employing the sit-down strike, forced General Motors to accept their organization after numerous abortive efforts. But the United Auto Workers (UAW) did not rely intensively on CIO monies for its organizing success nor on Lewis or other CIO leadership for its operations. The history of the union is a story of workers trying to organize, subject to generally bungled efforts by the AFL to provide leadership and aided only modestly by the CIO leadership.

The organization of the steelworkers was quite different. In steel, the CIO set up and funded the Steelworkers Organizing Committee (SWOC), and the United Mine workers provided organizers and money as well as Philip Murray, the Steelworkers Union's first president. Much of the growth, however, came by gaining the support of the company unions that the steel firms had set up to buffer themselves from independent unions, which makes it clear that there was an important bottom-up character to this drive as well. Still, the great success of the SWOC came with the negotiations between Lewis and the head of the U.S. Steel 
Corporation, Myron Taylor--a closed door meeting that organized the largest company without a strike. The Steelworkers are the prime example of a union that fits the top-down model.

To what extent did the organization of workers in CIO unions follow the UAW bottomup pattern as opposed to the Steelworkers top-down pattern? One way to answer this question is to categorize CIO unions according to the financial and organizing resources that the federation gave them and to contrast the membership or growth of membership in those unions over the relevant time period. Table 7 presents data on the amount of money the CIO gave to various unions from 1935 to 1941, and gives the dollars per member of each union in 1937. While financial support is not the sole indicator of CIO effort, it is an important measure of how involved the central federation was in particular organizing campaigns. The table shows wide variation in the absolute amount of money given and in the amount given per member. Consistent with the history of unionization in autos and steel, the UAW received relatively little money while the Steelworkers obtained a lot. Table 8 contrasts the 1942 membership in the various $\mathrm{CIO}$ unions according to the amount of CIO support given per member in 1937. I treat the unions receiving less than $\$ 2.00$ per 1937 member as organized independently of the CIO; those receiving more than $\$ 5.00$ per member as being dependent on the CIO; while unions receiving between $\$ 2.00$ and $\$ 5.00$ I categorize as being in an intermediate group. A classification of this type, based on a single indicator, is rough but, as noted in the Auto and Steel cases, my classification is generally consistent with the histories of particular unions. The striking fact is that in 1942 the CIO was not dominated by unions whose formation and growth had not depended greatly on CIO financial and organizing support. There are more than twice as many members in the unions that received relatively little CIO financial support than in 
those that received considerable support. One reason for this is that the CIO gave considerable money to some organizing drives, such as for construction workers, that had relatively little success (and were motivated less by the desire of workers to join CIO unions than by John L. Lewis' desire to create troubles for the AFL craft unions).

The most dramatic histories of the Depression-spurt focus on the growth of the new CIO industrial unions, but a major component of union expansion in the period was the AFL response to the new competing federation (Galenson 1960). Indeed, the absolute growth of membership in AFL unions exceeded the growth in CIO unions, even if we count the CIO as having no members prior to 1937 (although some founding organizations like the Miners were already large).

Between 1935 and 1942 the AFL gained 2.7 million members compared with a gain of 2.5 million for the CIO (see Table 9). Several AFL unions made particularly large gains in the period: the Machinists, which had opposed industrial unionism in internal AFL debates, but which transformed itself into "one of the great mass production unions in the country" (Galenson 1960, p. 141), in part to compete with the UAW in areas like airplane production; the Teamsters, which developed regional conferences to create a multi-industry general transport workers union; the Carpenters (whose head Bill Hutcheson was the man Lewis punched when he quit the AFL to form the CIO); the Railway Clerks; and the Building Laborers; though membership grew in other unions as well. To some extent, AFL unions were galvanized to fight for membership by rival CIO unions who threatened their jurisdiction rather than by the opportunities created by the Wagner Act election procedure per se. But they were also galvanized by worker desires to unionize in response to the Depression conditions. 
The problem for the AFL unions was to get their "act in gear" to take advantage of a market opportunity created more by worker desires than by government legislation.

Only three AFL (later CIO) unions exploited the opportunity first created by the Roosevelt Administration's NIRA to build or rebuild their membership base: the United Mine Workers (UMW), the Almagamated Clothing Workers (ACW), and the International Ladies Garment Workers Union (ILGWU). All three unions operated competitive industries. All had experienced periods of great growth followed by collapses throughout their histories. From 1927 to 1933 in particular, the UMW, then the largest exemplar of industrial unionism in the United States, had suffered massive losses of membership. The success of each of these unions depended critically on establishing some form of national or at least regional wage pattern, so that firms that signed with the union were not driven out of business by nonunion competitors. Thus the NIRA gave them a particular institutional setting through which to develop sectoral agreements. The UMW accomplished this in part through bargaining with the bituminous coal manufacturers federation and effectively helping them to oligopolize the industry. The ACW and ILGWU did the same in the major apparel producing areas in the North, but failed to extend their organization to the South. Most of the successful new CIO unions, by contrast, were in industries dominated by a few large employers, often located in a single area: Steel, Autos, Rubber. The great success of the AFL construction unions in the late 1930s reflected their monopoly of skilled crafts workers in particular localities, where organization depended largely on the activities of local unionists. 
In sum, to understand the development of unionism in the Great Depression, it is more useful to think of an endogenous bottom-down response operating in a period of great change in worker desire for unionism than of a legalistic top-down led unionization drive.

\section{Conclusion: What Does A Defining Period Define?}

For a particular event to be "defining," it must lock-in certain outcomes that persist into some future period when, given a blank slate, the society could have developed something very different. Historians and labor analysts writing in 1950s and 1960s believed that the Depression-spurt and the Wagner Act were such events, producing a substantial and stable collective bargaining system for the United States. According to Fleming, the Wagner Act "unquestionably contributed enormously to the growth of a large and independent labor movement ... and to the ... acceptance of that movement as a desirable part of a modern American society" (Fleming 1957, p. 149). Bernstein wrote that "American labor history took an eventful turn with the coming of the New Deal" $(1971, p$. ix). In 1964 Taft contrasted the labor movement "of today" with the "one that existed in the early 1930s," noting that "its numbers are about six times as great, and the level upon which it operates its legal, political, and research activities has been greatly expanded" $(1964$, p. 708$)$.

In 1997 the effect of the Depression and World War II spurt on union density and the U.S. labor relations system appears quite different. Private-sector union density has dropped to the levels of the mid-1900s. The social accord that made unions a part of national decisionmaking has broken down. An increasing number of employers seek the "union-free" 
environment that only retrograde right-wing ideologues once sought. Many firms that do not espouse the union-free world act as if that is what they truly want when their own work force seeks to organize. The Depression and World War II growth of unionism thus looks more like a diversion from American "exceptionalism"--a long and important diversion, but a diversion nonetheless--rather than a critical turning point in labor relations.

This does not, however, mean that the period did not leave a lasting legacy. What remains to this day is the nation's legal framework for conducting private sector labor relations: a national labor code, based on the Wagner Act as amended in ensuing years. This is a framework that is arguably outmoded. One major purpose of the Act--to encourage collective bargaining--has failed: the proportion of nonagricultural workers in unions is below what it was in the five Depression years prior to its enactment. From the union side, the Wagner Act turned the process of unionization into a legalistic business, in which firms and union organizers battle before the NLRB and courts as part of the election process. The protections that the Act gave to workers who want to unionize have de facto been eliminated, as the number of unfair practices committed by employers per election has risen sharply. Never envisaging a world in which upwards of 35 percent of non-managerial workers would supervise others, where white-collar managerial and professional jobs would constitute the dominant occupations, the Act, with its Taft-Hartley Amendments, fails to provide any place for intermediate organizations--staff associations, works councils, or more pejoratively company unions--that some of these workers may prefer to the stark collective bargaining or nothing choice that the Wagner Act offers. The labor relations code provides no place for unions of supervisors, professionals, nor managers. From the employer side, the Act makes it 
illegal for firms to set up and support worker organizations that might give some legitimate voice to workers who want some organization at their workplace short of an independent union which bargains collectively (the "company union"). Perhaps most importantly, the NLRB representation procedure has not reduced the confrontation between management and employees over unionization, but has simply transformed it from one setting to another. By contrast, state regulation of public sector labor relations has produced what the Wagner Act has not--a stable collective bargaining system in that part of the economy with much less confrontation in the organizing process. As the laws in the public and private sector are at this writing reasonably similar, I have argued that the reason for this difference is the difference in the incentive and willingness of private sector managers to oppose organization than of public sector managers, presumably for reasons of corporate profit.

My view that the Wagner Act has locked the United States into an outmoded labor relations framework that does not fit labor market realities as the country moves into the twenty-first century is not an isolated one. Many labor experts concur that the Wagner Act framework no longer fits the U.S. economy, though they often disagree about the specifics of labor law reform, as can be seen in the differing views given by labor, management, and independent scholars before the 1993/1994 Commission on the Future of Worker-Management Relations (U. S. Department of Labor, 1994). The workers, firms, union membership, and economy have changed greatly since the 1930s. But, despite several amendments to the Wagner Act, the basic structure of the law has not changed, creating an institutional straightjacket that helps neither U.S. workers, firms, nor unions, but one that has proven difficult to change, given the fears of labor and managment that any shifts in the law will tilt 
the balance of power against their side. The lesson I draw from the Depression-spurt is that these fears are probably ill-placed. No plausible "labor law reform" is likely to induce a burst of unionism in the United States. The lesson from the Depression experience is that bottom-up employee driven burst of union activity rather than particular laws are necessary for any resurgence of union density. Another lesson is that any such resurgence of unionism will come suddenly, probably surprising the current crop of experts and labor historians as much as the Depression spurt surprised Barnett and other observers in the period. 


\section{References}

Ashenfelter, Orley and John H. Pencavel. "American Trade Union Growth, 1900-1960," Quarterly Joumal of Economics 83(3) (August 1969): 434-48.

Bain, G.S. and Robert Price. Profiles of Union Growth. Oxford, England: Basil Blackwell, 1980.

Barnett, George Harold, Presidental Address to the 45th Annual Meeting of the AEA, Cincinnati, Ohio, December 29, 1932), American Economic Association Papers and Proceedings, 1933.

Bernstein, Irving. The New Deal Collective Bargaining Policy. University of California Press, 1950.

-----. The Turbulent Years. New York: Houghton-Mifflin, 1971.

Bureau of National Affairs, Union Membership and Earnings Data Book 1994. Washington: Bureau of National Affairs, 1995.

Bureau of National Affairs, Directory of U.S. Labor Organization, 1982-83 Edition. Washington: Bureau of National Affairs, 1983.

Burns, James MacGregor. Roosevelt: the Lion and the Fox. New York: Harcourt Brace Jovanovich, 1956.

Commons, John R., David J. Saposs, Helen L. Sumner, E.B. Mittelman, H.E. Hoagland, John B. Andrews, and Selig Perlman. History of Labour in the United States. New York: Macmillan, 1918. 
Council of Economic Advisors. Economic Report of the President 1996. Washington, DC: United States Government Printing Office, 1996.

Davis, Horace B. "The Theory of Union Growth," Quarterly Journal of Economics 55 (August 1941): pp 611-637.

Derber, Milton and Edwin Young. Labor and the New Deal, Madison, Wisconsin: University of Wisconsin Press, 1957.

Dunlop, John T. "The Development of Labor Organization: A Theoretical Framework," in Insights into Labor Issues, edited by Richard A. Lester and Joseph Shister. New York: Macmillan, 1948: 163-193.

Edelman, Murray. "New Deal Sensitivity to Labor Interests," in Labor and the New Deal, edited by Milton Derber and Edwin Young. Madison, Wisconsin: University of Wisconsin, 1957.

Fleming, Robben Wright. "The Significance of the Wagner Act" in Derber Milton and Edwin Young, Labor and the New Deal (University of Wisconsin, Madison, 1957).

Friedel, Frank. EDR--Launching the New Deal, Boston: Little-Brown, 1973

Friedman, Gerald. New Estimates of Union Membership, the United States, 1880-1914. University of Massachusetts mimeo, October 1995

Freeman, Richard B. "Unionism Comes to the Public Sector," Journal of Economic Literature 24 (March 1986): pp 41-86.

Galenson, Walter. The CIO Challenge to the AFL. Cambridge, MA: Harvard University Press, 1960. 
Giebisch, Robert. "The Impact of the Wagner Act on Trade Union Growth" Economics 1650, Harvard University, January 1, 1979.

Goldfield, M. Labor's Subordination to the New Deal: Part II, American Political Science Review (September 1987).

Goldfield, M. The Decline of Organized Labor in the United States. Chicago: University of Chicago, 1987.

Klare, Karl. "Judicial Deradicalization of the Wagner Act", Minnesota Law Review (Fall 1978).

Leuchtenberg, William. Eranklin D. Roosevelt and the New Deal, New York: Harper and Roe, 1963.

Millis, Harry A. and Emily Clark Brown. Erom the Wagner Act to Taft-Hartley. Chicago, IL: University of Chicago Press, 1950.

OECD (Organization for Economic Cooperation and Development). Employment Outlook July 1991. Paris, France: OECD, 1991.

Taft, P. Organized Labor in American History, New York: Harper and Row, 1964.

Troy, Leo Trade Union Membership. 1897-1962. New York: NBER and Columbia University Press, 1965.

Troy, Leo and Neil Sheflin. Union Sourcebook. West Orange, NJ: IRDIS, 1985.

Schlesinger, Arthur M. The Coming of the New Deal, Boston: Houghton Mifflin, 1958.

Schneider, Michael. A Brief History of German Trade Unions. Bonn, Germany: J.H.W. Dietz, 1991. 
United States Bureau of the Census. Historical Statistics of the United States, Colonial Times to 1957 Washington, DC: United States Government Printing Office, 1960.

United States Bureau of the Census. Long-term Economic Growth, 1860-1965. Washington, DC: United States Government Printing Office, 1966.

United States Department of Commerce. The National Income and Product Accounts of the United States. 1929-1965: Statistical Tables. Washington, DC: United States Government Printing Office, 1966.

United States Department of Labor, Bureau of Labor Statistics. Employment and Earnings. January Issues. Washington, DC: United States Government Printing Office, 19861996.

United States Department of Labor, Bureau of Labor Statistics. Handbook of Labor Statistics 1977 Bulletin 1500 Washington, DC: United States Government Printing Office, 1978.

United States Department of Labor, Bureau of Labor Statistics. Directory of National Unions and Employee Associations 1979 Bulletin 2079 Washington, DC: United States Government Printing Office, 1980.

United States Department of Labor. Fact Finding Report: Commission on the Future of Worker-Management Relations. Washington, DC: United States Government Printing Office, May 1994.

----. Report and Recommendations: Commission on the Future of Worker-Management Relations. Washington, DC: United States Government Printing Office, December 1994. 
Woytinsky, W.S. and Associates. Employment and Wages in the United States. New York: Twentieth Century Fund, 1953.

Visser, Jelle. European Trade Unions in Figures. Netherlands: Deventer, 1989.

-----. Trade Union Membership Database. Amsterdam, March 1992. 
Figure 1: Changing Percentage of Non-Agricultural Workers Who Are Members of Unions, $1880-1995$

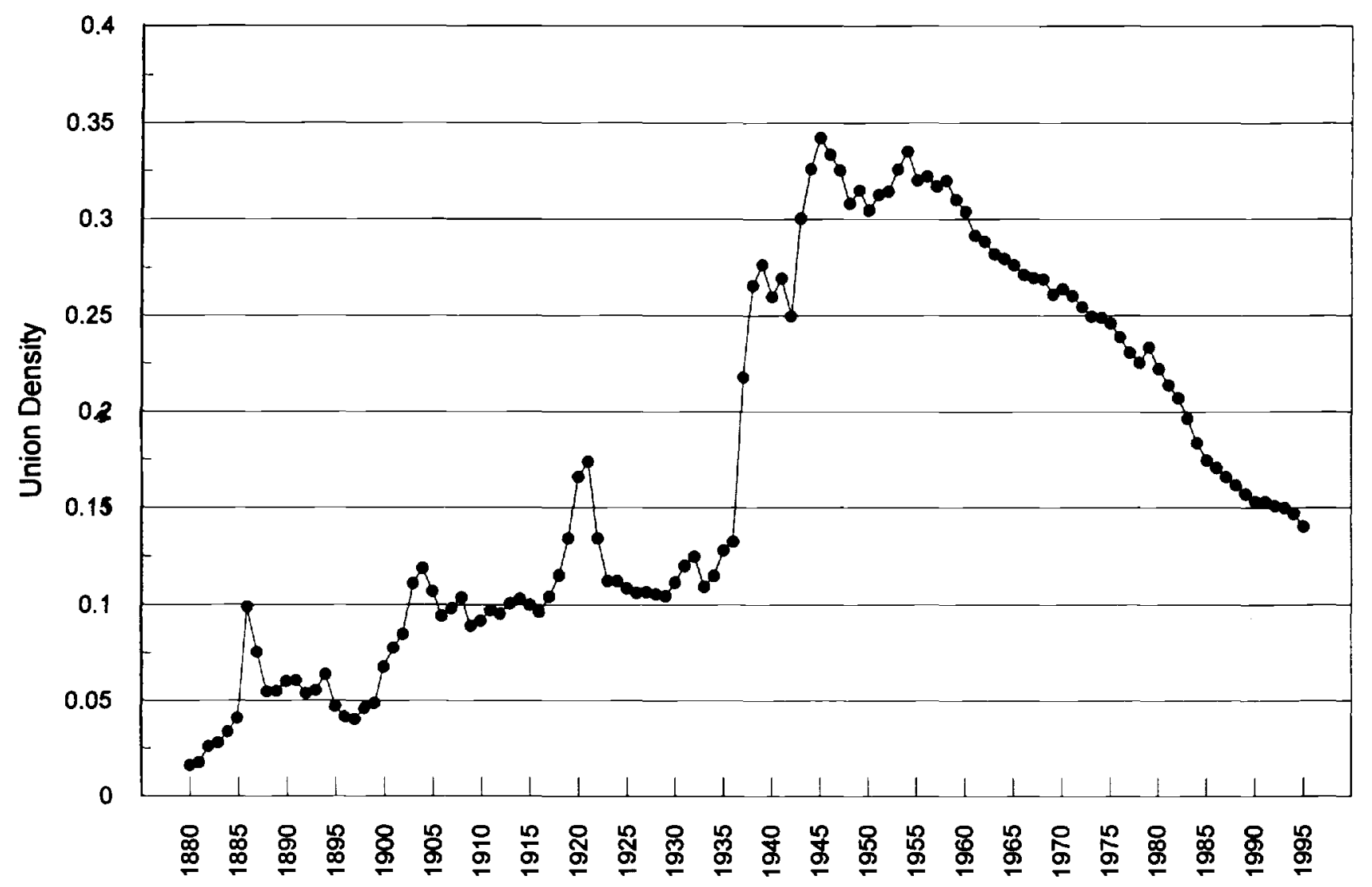

Source: See Appendix A, this paper. 
Figure 2: Nonlinearity and Spurts

PART A:

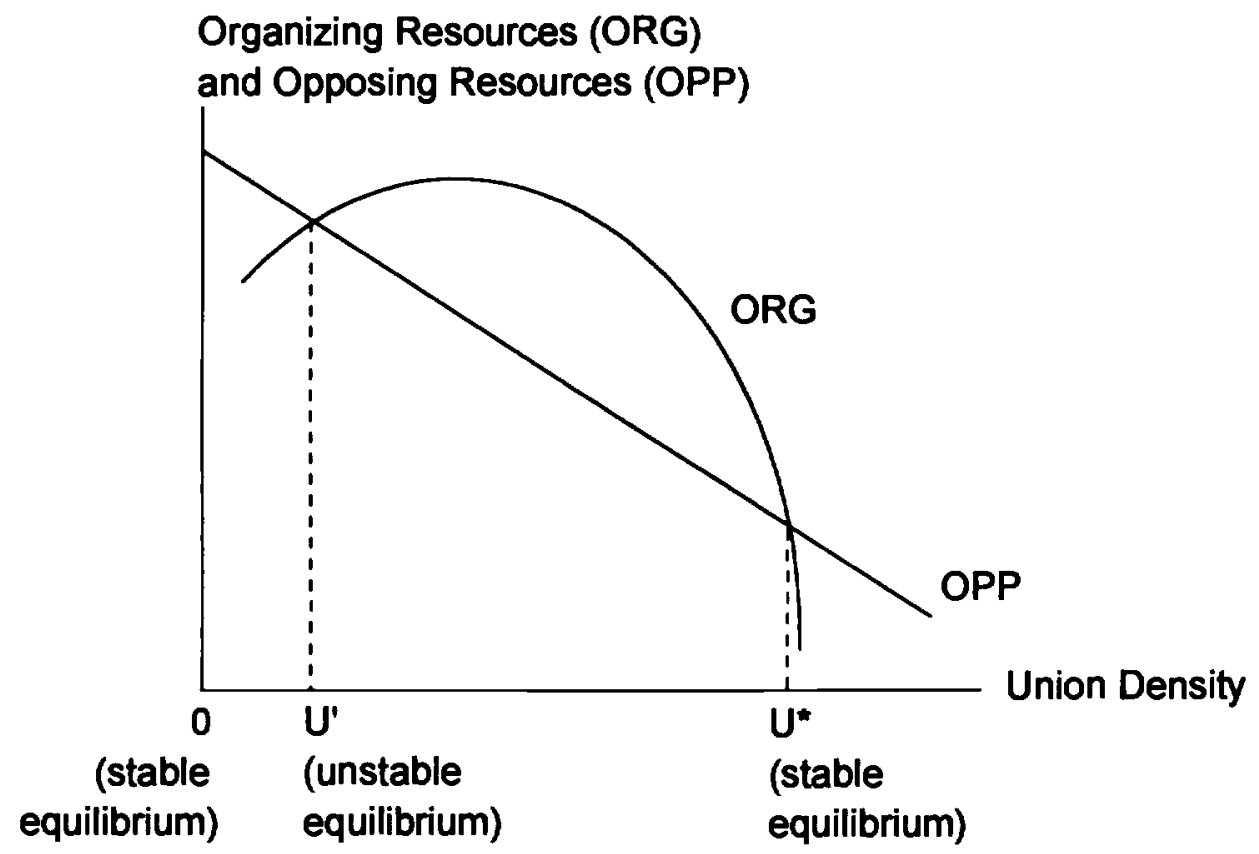

PART B:

Organizing Resources (ORG)

and Opposing Resources (OPP)

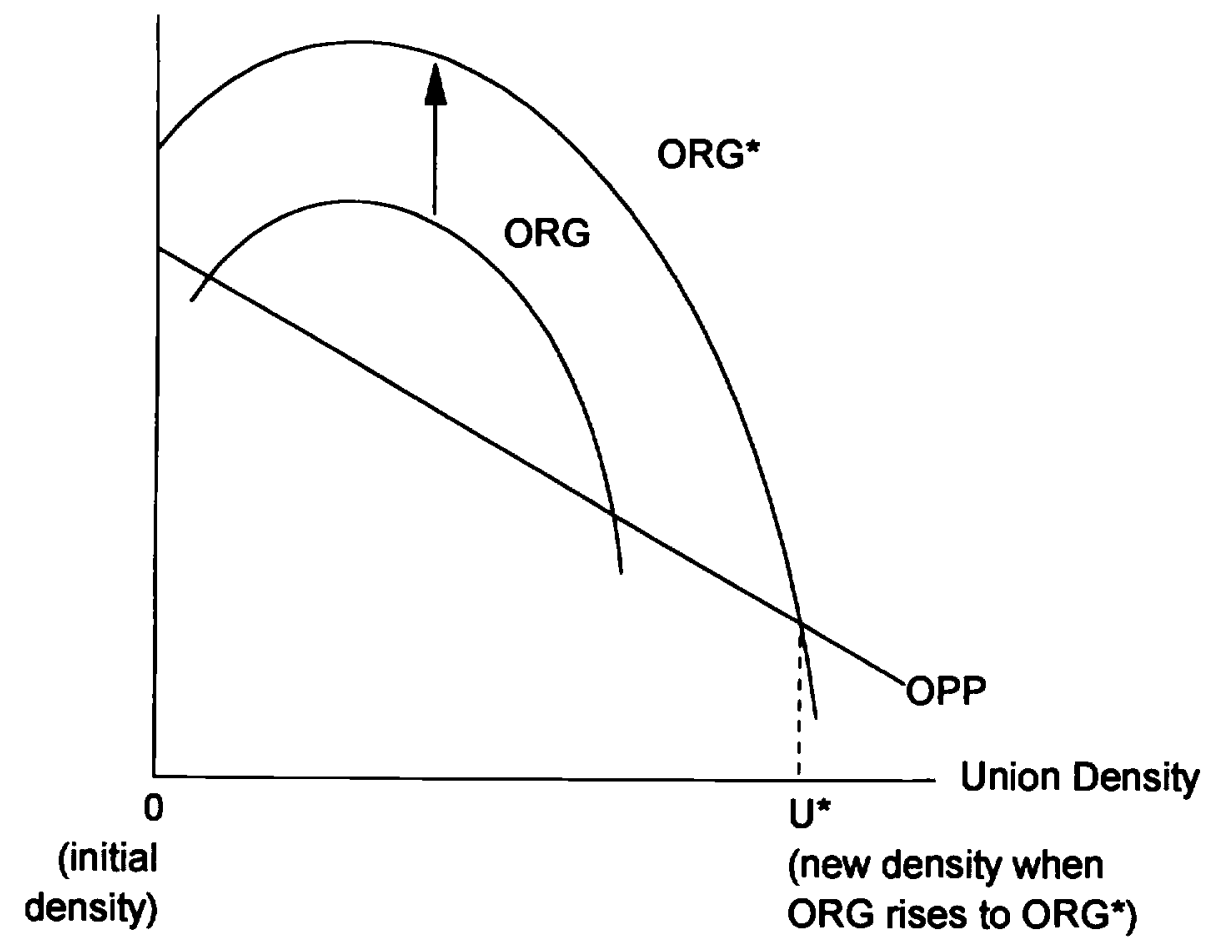


Table 1: Changes in Union Density in Periods of Spurts and Other Periods, 1880-1995

\begin{tabular}{|c|c|c|c|c|c|c|}
\hline \multirow[t]{2}{*}{ Years } & \multicolumn{2}{|c|}{ Density } & \multicolumn{2}{|c|}{$\begin{array}{l}\text { Years When } \\
\text { Density Grew }\end{array}$} & \multicolumn{2}{|c|}{$\begin{array}{l}\text { Years When } \\
\text { Density Fell }\end{array}$} \\
\hline & Initial & Final & \# Years & $\begin{array}{c}\text { Average } \\
\Delta \text { Density }\end{array}$ & \# Years & $\begin{array}{c}\text { Average } \\
\Delta \text { Density }\end{array}$ \\
\hline \multicolumn{7}{|l|}{ Spurts } \\
\hline $1883-1986$ & 2.8 & 9.9 & 3 & 2.4 & & \\
\hline 1899-1904 & 4.9 & 11.9 & 5 & 1.4 & & \\
\hline 1916-1921 & 9.6 & 17.4 & 5 & 1.6 & & \\
\hline 1934-1939 & 11.5 & 27.6 & 5 & 3.2 & & \\
\hline $1942-1945$ & 25 & 34.2 & 3 & 3.1 & & \\
\hline All & & & 21 & 2.2 & & \\
\hline \multicolumn{7}{|l|}{ Nonspurts } \\
\hline $1880-1883$ & 1.7 & 2.8 & 3 & 0.4 & & \\
\hline $1886-1899$ & 9.9 & 4.9 & 7 & 0.3 & 6 & -1.3 \\
\hline 1904-1916 & 11.9 & 9.6 & 6 & 0.4 & 6 & -0.8 \\
\hline $1921-1934$ & 17.4 & 11.5 & 6 & 0.4 & 7 & -1.2 \\
\hline 1939-1942 & 27.6 & 25 & 1 & 1.0 & 2 & -1.8 \\
\hline $1945-1995$ & 34.2 & 14.9 & 10 & 0.5 & 40 & -0.6 \\
\hline $1945-1970$ & 34.2 & 26.4 & 8 & 0.5 & 17 & -0.7 \\
\hline $1970-1995$ & 26.4 & 14 & 2 & 0.5 & 23 & -0.6 \\
\hline All & & & 33 & 0.5 & 61 & -0.8 \\
\hline
\end{tabular}

Source: Tabulated from union density statistics in Appendix Table A.

Notes: The average density in the spurt period is simply the average annual change in the specified years. The average densities in the nonspurt periods are the average annual changes in the years when density grew and when density fell. The "all" figures are the averages of the change in density in the specified spurt years. 
Table 2: Percentage Growth of Union Membership in Selected Unions during "Spurts"

$1897-1904 \quad 1916-1921 \quad 1934-1939 \quad 1942-1945$

\begin{tabular}{|c|c|c|c|c|}
\hline \multirow[b]{2}{*}{ Automobile } & \\
\hline & -- & -- & * & 51 \\
\hline Boilermakers & 717 & 212 & 113 & -45 \\
\hline Bricklayers & 55 & 11 & 41 & 0 \\
\hline Carpenters & 367 & 54 & 22 & $162^{a}$ \\
\hline Clothing/Textile & -- & 172 & 88 & 4 \\
\hline Communication & -- & - & -- & $138^{b}$ \\
\hline UE (United Electrical Workers) & -- & -- & 122 & \\
\hline $\begin{array}{l}\text { IBEW (International Brotherhood } \\
\text { of Electrical Workers) }\end{array}$ & 667 & 294 & 27 & 13 \\
\hline Operating Engineers & 900 & 52 & 66 & 4 \\
\hline Food \& Commercial & 949 & 31 & 735 & 57 \\
\hline ILGWU & - & $345^{c}$ & 6 & 21 \\
\hline Glass/Pottery/Plastic & 50 & 5 & 259 & 42 \\
\hline Hotel \& Restaurant & 1,333 & -3 & 275 & 6 \\
\hline Ironworkers & $100^{d}$ & 55 & 167 & -9 \\
\hline Laborers (Hod Carriers) & $*$ & 44 & 267 & -56 \\
\hline Longshore & 722 & 131 & 83 & 1 \\
\hline Machinists & 308 & 132 & 92 & 37 \\
\hline Maintenance of Way & - & 385 & 133 & 14 \\
\hline Musicians & 118 & 24 & 29 & 21 \\
\hline
\end{tabular}


Operating Engineers

Painters

Plumbers

Railway Clerks

Retail and Wholesale

Rubber

Service Employees

Sheetmetal Workers

Steelworkers

Teamsters

Transit (Street \& Motor)

Transport Workers

UFCW (United Food and

Commercial Workers)

UMW

Utility Workers

Woodworkers
1856

756

240

$540^{\text {eee }}$

2689

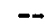

$-$

$-$

1218

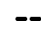

$2941^{f}$

934

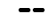

1329

1370

20

$-7$

$-16$

25

25 
Table 2, continued:

Notes: "--" means that the data were unavailable, usually because the union did not exist during the observation period. The Troy and Sheflin (1985) data differ somewhat from Troy (1965) for the same time periods. When available, I used the Troy and Sheflin data.

*Union was newly created during this time period.

${ }^{2}$ Numbers reported are for the period 1940-46.

Numbers reported are for the period 1939-46.

Numbers reported are for the period 1909-16.

Numbers reported are for the period 1901-03.

'Numbers reported are for the period 1900-04.

${ }^{\mathrm{f}}$ Numbers reported are for the period 1899-1904.

Source: Troy and Sheflin (1985), Appendix B. Troy (1965), Tables A1 and A2. 
Table 3: A Century of Change in Unionization in the Developed World

\begin{tabular}{llcc} 
Period & \multicolumn{1}{c}{$\begin{array}{c}\text { Qualitative } \\
\text { Characterization }\end{array}$} & $\begin{array}{c}\text { Mean } \\
\text { Change } \\
\text { in } \\
\text { Density }\end{array}$ & $\begin{array}{c}\text { \# of Countries that Fit } \\
\text { the qualitative } \\
\text { characterization }\end{array}$ \\
\hline $1900 \mathrm{~s}$ & increasing union density & 9 & 7 of 7 rise \\
$1910-16$ & stability & 0 & 6 rise; 6 fall \\
World War I & spurt in density & 19 & 12 of 12 rise \\
1920 s & fall in density & -9 & 10 of 12 fall \\
Mid-1930s/World War II & spurt & 19 & 10 of 10 rise \\
$1950 \mathrm{~s}$ & stability & -2 & 10 of 14 modest changes \\
$1960 \mathrm{~s}$ & stability & 0 & 12 of 14 modest changes \\
$1970 \mathrm{~s}$ & growth with diversity & 5 & 13 of 18 rise \\
$1980 \mathrm{~s} / 1990 \mathrm{~s}$ & fall in density & -6 & 13 of 18 fall
\end{tabular}

Notes: Countries covered are Austria, Denmark, Finland, France, Germany, Ireland, Italy, Japan, Luxemburg, Netherlands, Norway, Sweden, Switzerland, United Kingdom, United States, Canada, Australia, and New Zealand. The mean change in density is the unweighted average change in density for the countries over the relevant period.

1900s: the seven countries are: United States, United Kingdom, Germany, Sweden, Denmark, Norway, Australia

1910s: additional five countries are: Canada, France, Italy, Netherlands, Switzerland 1920s: exceptions are Sweden and Australia

1930s/World War II: Missing countries are Germany and Austria

1950s: Norway rises; Italy, France, Japan have sharp falls 
Table 3, continued

1960s: Italy rises; Switzerland falls

1970s to 1990s: OECD (1991)

Sources: Visser (1989); Bain and Price (1980); Schneider (1991); OECD (1991). 
Table 4: Union Density in the 1930s in Western Countries

\begin{tabular}{lccc} 
& \multicolumn{2}{c}{ Density and Date } & \multicolumn{2}{c}{ Average Annual } \\
\cline { 2 - 3 } & Before Spurt & At Peak Spurt & Change per Year \\
\hline Australia & $34.9(1933)$ & $38.8(1939)$ & 0.7 \\
Canada & $17.6(1936)$ & $22.2(1938)$ & 2.3 \\
Denmark & $36.2(1929)$ & $46.6(1939)$ & 1.0 \\
France & $7.0(1935)$ & $25.4(1937)$ & 9.2 \\
Netherlands & $26.3(1928)$ & $43.0(1932)$ & 4.2 \\
Norway & $13.2(1927)$ & $42.9(1939)$ & 2.5 \\
Sweden & $37.9(1933)$ & $53.7(1939)$ & 2.6 \\
Switzerland & $21.1(1928)$ & $27.7(1932)$ & 1.7 \\
United Kingdom & $22.6(1933)$ & $33.1(1940)$ & 1.5 \\
United States & $11.9(1934)$ & $28.6(1939)$ & 3.3
\end{tabular}

"Denmark had fairly steady growth before and after the Depression.

Sources: Bain and Price (1980); Visser (1989). 
Table 5: Union Density of Industries in the Depression-World War II Spurt

Industry

Year

\begin{tabular}{|c|c|c|c|c|}
\hline & 1933 & 1935 & 1939 & 1947 \\
\hline Manufacturing & - & 10.6 & 22.8 & 40.1 \\
\hline Manufacturing ${ }^{\mathbf{b}}$ & 13.6 & - & 23.1 & 40.2 \\
\hline Metals and machinery & 11.0 & - & 24.5 & 49.6 \\
\hline Clothing & 51.6 & - & 53.8 & 60.9 \\
\hline Food, drink, and tobacco & 5.5 & - & 24.1 & 29.6 \\
\hline Paper, printing, and publishing & 20.5 & - & 28.7 & 38.2 \\
\hline Leather and leather products & 23.1 & - & 16.7 & 41.4 \\
\hline Chemicals, rubber, clay, glass, and stone & 4.4 & - & 13.2 & 26.3 \\
\hline Textiles & 1.5 & - & 7.1 & 30.2 \\
\hline Lumber and lumber products & 10.0 & - & 11.1 & 16.0 \\
\hline Transportation, communication, and utilities & - & 27.9 & 50.0 & 70.8 \\
\hline Railway transportation & - & - & 58.3 & - \\
\hline Building and construction & - & 55.3 & 77.3 & 89.0 \\
\hline Mining, quarrying, and oil & - & 71.7 & 65.4 & 69.3 \\
\hline Government & - & 8.8 & 10.5 & 11.6 \\
\hline Services & - & 2.8 & 6.0 & 9.2 \\
\hline
\end{tabular}


Table 5, continued

This line is from Bain and Price (1980), table 3.3.

'These lines are obtained by dividing union membership from Bain and Price (1980) table 3.4 by employment data from the U.S. Department of Commerce.

Source: Bain and Price (1980) and U.S. Department of Commerce (1966). 
Table 6: Number of Workers Organized by Way of Recognition Strikes and by NRLB Elections

\begin{tabular}{|c|c|c|c|c|c|c|}
\hline Year & $\begin{array}{c}\text { Number of } \\
\text { Recognition } \\
\text { Strikes }\end{array}$ & $\begin{array}{c}\text { Numbers of } \\
\text { Workers in } \\
\text { Recognition } \\
\text { Strikes }\end{array}$ & $\begin{array}{c}\text { Number of } \\
\text { Workers in } \\
\text { Recognition } \\
\text { Strikes }\end{array}$ & $\begin{array}{l}\text { Number of } \\
\text { Recognition } \\
\text { Elections }\end{array}$ & $\begin{array}{l}\text { Numbers of } \\
\text { Workers in } \\
\text { Election Units } \\
\text { Voting Union }\end{array}$ & $\begin{array}{c}\text { Percentage of } \\
\text { Workers } \\
\text { Unionized by } \\
\text { Recognition } \\
\text { Strikes }\end{array}$ \\
\hline 1934 & 562 & 701,101 & 554,755 & 528 & 30,000 & 95 \\
\hline 1935 & 560 & 202,118 & 163,513 & - & - & - \\
\hline 1936 & 809 & 272,013 & 225,498 & 163 & 74,000 & 75 \\
\hline 1937 & 2200 & 941,802 & 711,060 & 708 & 262,000 & 73 \\
\hline 1938 & 867 & 110,398 & 86,104 & 949 & 286,000 & 24 \\
\hline 1939 & 885 & 132,034 & 99,817 & 69 & 373,000 & 21 \\
\hline 1940 & 767 & 71,054 & 58,051 & 1880 & 657,000 & 9 \\
\hline 1941 & 1466 & 444,551 & 337,868 & 3390 & $1,001,000$ & 25 \\
\hline 1942 & 684 & 59,876 & 47,906 & 4182 & $1,281,000$ & 4 \\
\hline 1943 & 244 & 71,764 & 57,411 & 4432 & $1,253,000$ & 4 \\
\hline 1944 & 389 & 213,387 & 29,875 & 4815 & $1,084,000$ & 3 \\
\hline 1945 & 592 & 436,500 & 103,320 & 5253 & 773,000 & 12 \\
\hline
\end{tabular}

Notes: I estimated the number organised by recognition strikes by multiplying the number reported involved in those strikes by the percentage of workers the BLS reported as being involved in recognition strikes where the outcome was substantial or partial gains to the union. Election statistics are from National Labor Relations Board, Annual Report, June 1936-June 1946, with the monthly NLRB data adjusted from a fiscal year basis to be on a calendar year comparable to the strike data. From 1936 to 1945 the NLRB reported the number of workers eligible to vote 
Table 6, continued

and the number who voted union but not the number in elections where the union won. In a term paper (Giebisch 1979), Robert Giebisch estimated that the number of workers in units won by the union was $15 \%$ higher than the number who voted union. The numbers in the column for workers in units voting union are based on this adjustment.

Source: Recognition strike data from the U.S. Bureau of Labor Statistics, Monthly Labor Reviews, Jan 1986, May 1936-1946. 
Table 7: Assistance Given by the CIO to National Affiliates, 1935-1941 and Estimated Assistance Per Member in the Affiliates as of 1937

\begin{tabular}{|c|c|c|}
\hline Union & Assistance in thousands of $\$$ & Assistance per Member in $\$$ \\
\hline Aluminum Workers & $\$ 30$ & $\$ 1.17$ \\
\hline Architects & 44 & 12.09 \\
\hline Automobile & 60 & .31 \\
\hline Barbers & 3 & 6.00 \\
\hline Cannery & 88 & \\
\hline Communication & 68 & 6.18 \\
\hline Construction & 313 & 125.20 \\
\hline Die Casters & 13 & 2.60 \\
\hline Distillers & 30 & \\
\hline Farm Equipment & 72 & 1.45 \\
\hline Federal & 108 & 33.75 \\
\hline Flat Glassblowers & 14 & .82 \\
\hline Furniture & 54 & 4.25 \\
\hline District 50, UMW & 110 & 12.09 \\
\hline Inland Boatmen & 9 & 2.90 \\
\hline Iron, Steel, and Tin & 20 & 1.03 \\
\hline Longshore & 29 & 1.16 \\
\hline Marine Engineers & 1 & .8 \\
\hline Marine \& Shipbuilding & 52 & 2.67 \\
\hline Maritime & 49 & 1.67 \\
\hline Mine, Mill, and Smelter & 62 & 3.18 \\
\hline Newspaper Guild & 41 & 3.59 \\
\hline Office and Professional & 66 & 7.59 \\
\hline Oil & 117 & 6.92 \\
\hline Packinghouse Workers & 93 & 2.94 \\
\hline
\end{tabular}




$\begin{array}{lcc}\text { Stone } & 1 & .2 \\ \text { Radio and Telegraph } & 33 & 66.00 \\ \text { Retail and Department } & 121 & 3.02 \\ \text { Rubber } & 23 & .74 \\ \text { Shoe } & 82 & 4.77 \\ \text { State, Municipal \& City } & 134 & 23.10 \\ \text { Steel } & 1,019 & 8.15 \\ \text { Textiles } & 133 & 1.97 \\ \text { Toy and Novelty } & 53 & 11.04 \\ \text { Utility } & 76 & 9.50 \\ \text { Woodworkers } & 85 & 4.36 \\ \text { Studio Technicians } & 4 & 1.53 \\ \text { Optical } & 4 & 2.50 \\ \text { Electrical and Radio } & 52 & 1.68\end{array}$

Source: Column 1, from Galenson (1960) table 26; column 2, I divided column 1 by union membership in 1937 from Troy (1965), table A-2. When Troy reported no membership in a give year, I have taken the membership in the nearest available year. 
Table 8: Membership in CIO Unions in 1942, According to Dependence on CIO for Financial Assistance

$\begin{array}{cccc}\text { Dollars of Aid, 1935-1941, } & \text { Number of } & 1942 & \text { Major Unions in Group } \\ \text { per } 1937 \text { member } & \text { Unions } & \text { Membership }\end{array}$

\begin{tabular}{llrl}
\hline$\$<2$ & 15 & $1,055,000$ & UAW, Electrical, Rubber \\
$\$ 2-5$ & 10 & 379,000 & Textile, Marine \& Shipbuilding \\
$\$ 5+$ & 12 & 584,600 & Steel, Construction District 50
\end{tabular}

Notes: Calculated from Table 7 and membership data from Troy (1965); table A-2. Includes only unions given some central support. Thus, ACW, UMW, and ILGWU, among others are excluded from the data. When a union was not affiliated with CIO (UMW, District 50 left with the UMW), I used the most recent CIO-affiliation year. 
Table 9: Membership in thousands in the AFL and CIO, 1935-1942

\begin{tabular}{lrrrrrrrr} 
& 1935 & 1936 & 1937 & 1938 & 1939 & 1940 & 1941 & 1942 \\
\hline \multicolumn{1}{c}{ AFL } & 3,218 & 3,516 & 3,180 & 3,547 & 3,878 & 4,343 & 5,179 & 6,073 \\
Machinists & 98 & 116 & 167 & 171 & 178 & 207 & 313 & 489 \\
Teamsters & 162 & 188 & 353 & 394 & 442 & 478 & 599 & 566 \\
Retail clerks & 12 & 18 & 24 & 30 & 51 & 74 & 83 & 80 \\
Bakers & 21 & 25 & 30 & 56 & 69 & 81 & 83 & 91 \\
Carpenters & 129 & 150 & 209 & 215 & 215 & 233 & 357 & 517 \\
Electrical & 57 & 67 & 94 & 107 & 125 & 146 & 202 & 277 \\
Hotel & 82 & 110 & 194 & 187 & 211 & 226 & 269 & 237 \\
Other Building Trades & & & & & & & & \\
Boilermakers & 15 & 16 & 18 & 28 & 29 & 33 & 43 & 90 \\
Bridge \& Iron & 13 & 17 & 32 & 42 & 39 & 41 & 63 & 94 \\
Operating Engineers & 35 & 35 & 42 & 42 & 58 & 64 & 97 & 138 \\
Painters & 64 & 75 & 93 & 101 & 103 & 114 & 131 & 127 \\
Plumbers & 35 & 37 & 44 & 54 & 59 & 62 & 81 & 114 \\
CIO & & & & & & & & \\
& -2 & $-1,991$ & 1,958 & 1,838 & 2,154 & 2,654 & 2,493
\end{tabular}

Source: Troy (1965); table A-1 


\section{Appendix A: Union Membership and Density Estimates}

There are alternative estimates of union membership for the United States that cover the Depression Era (and earlier) through the 1990s. These include Troy (1965), Troy and Sheflin (1985), and the Bureau of Labor Statistics (reported in diverse publications such as various Statistical Abstracts and BLS Bulletins, such as U.S. Bureau of Labor Statistics (1980). Galenson (1960, pp 584-587) reports different numbers for various unions in the Depression period and describes some of the problems of determining membership at a time when unions were competing. He also contrasts "his" estimates with those of Wolman. There are differences between convention strength and membership claims, differences between members in good standing, and dues paying members, that produce wide variation. Even the head of the CIO, Philip Murray was uncertain about memebership in 1939, when per capita payments gave a membership estimate of 1.7 million: "he indicated that many affiliates were not paying their per capita fees to the CIO, and that actual membership might be as high as $3,000,000$ " (Galenson 1960, p 585). The contemporaneous BLS estimate for 1939 was 4 million. Given these differences, it is not surprising that while all extant estimated series show a sharp increase in membership from 1935 through 1939 and from 1941 or 1942 through 1945, the timing and magnitude of the changes does differ, in some cases for reasons that are unclear. Below I report five different union membership series for 1933-1948 that show the range of variation in these estimates: 


\begin{tabular}{|c|c|c|c|c|c|}
\hline \multicolumn{6}{|c|}{ Union Membership (000s) } \\
\hline & BLS & Troy NBER & Troy \& Sheflin & Galenson & Wolman \\
\hline 1933 & 2857 & 2973 & 3659 & & \\
\hline 1934 & 3249 & 3609 & 4164 & & \\
\hline 1935 & 3728 & 3753 & 3794 & & \\
\hline 1936 & 4164 & 4107 & 4316 & 4164 & 4075 \\
\hline 1937 & 7218 & 5780 & 5923 & 5080 & 6334 \\
\hline 1938 & 8265 & 6080 & 6193 & 5944 & 7342 \\
\hline 1939 & 8980 & 6556 & 6708 & 6680 & 7735 \\
\hline 1940 & 8944 & 7282 & 7524 & 6669 & 8101 \\
\hline 1941 & 10489 & 8698 & 9017 & 8339 & 8614 \\
\hline 1942 & 10762 & 10200 & 10569 & & \\
\hline 1943 & 13642 & 11812 & 12103 & & \\
\hline 1944 & 14621 & 12628 & 12605 & & \\
\hline 1945 & 14796 & 12562 & 12728 & & \\
\hline 1946 & 14974 & 13263 & 13515 & & \\
\hline 1947 & 15414 & 14595 & 14694 & & \\
\hline 1948 & 15000 & 15020 & 14953 & & \\
\hline
\end{tabular}

The differences among the series are largest in 1936 and 1937, when the BLS data shows a much greater spurt in membership than either the Troy or Troy and Sheflin or Galenson series. The Wolman series shows a large increase in membership 1936-1937, but still 
falls short of the change in membership in the BLS data. The differences in the series imply somewhat different timing and magnitudes for the Depression Era spurt, but all still show sizeable gains in membership. The BLS series also shows a larger increase in 1942-43 than the Troy or Troy and Sheflin series. But since the Troy and Troy and Sheflin data are roughly comparable to the BLS in 1948, they show larger estimated increases in union membership from 1944 to 1948 than does the BLS series.

Why do the series differ? The BLS and Troy data differ presumably because the Troy figures are based on dues paying membership while the BLS data are derived from union reports, which may include persons who do not pay dues, particularly in 1937. Troy and Sheflin are based on the earlier Troy figures, with adjustments from fiscal year to calendar year, but this does readily explain some of the differences between these series, particularly in 1933 and 1934. The Galenson series use AFL and independent union data together with Philip Murray's estimates for the CIO, which may have understated even dues-paying membership, as individual unions sought to keep more of the dues for themselves.

There is no strong reason to prefer the BLS or Troy or Troy and Sheflin data for analyzing union growth in the U.S. But becasue I am uneasy about the unexplained changes between the Troy estimates and the Troy and Sheflin estimates, and have a mild preference for measures that reflect the broadest possible membership in unions to those limited to annual dues-paying members, as the former may give a better indication of changes in periods of rapid growth, I base my estimates on the BLS series spliced to other series. Use of any of the other series or variants of the particular splicing that I chose will not, however, affect the basic findings or analysis. 
The estimates reported in Appendix table A1 provide one continuous union membership series from 1880 to 1995 , together with a single non-agricultural employment series, from which I derive a density series. The union membership figures refer to U.S. union members only. To obtain the figures, I splices together three different series. The 1995 numbers come from BLS, Employment and Earnings, January 1996. For the period 1983 to 1994, I use the numbers reported from the CPS in Bureau of National Affairs, Union Membership and Earnings Data Book. 1993 (1995), table 1 with the 1981 number based on the reported percentage of wage and salary workers who were union members. As there are no numbers for 1982, I estimated membership in that year by assuming the change between 1981 and 1983 was proportionate to the change given in Troy and Sheflin (1985), table 3-10. For 1978-1980, I use the CPS numbers reported in Bureau of National Affairs, Directory of U.S. Labor Organizations 1982-1983 edition (1982), table 1. From 1930 to 1977, I use the series reported by the Bureau of Labor Statistics (1980), spliced to be consistent with the CPS at the 1978 overlap year between the BLS and CPS series. For the period 1897 to 1929 I use the BLS series reported in U.S. Bureau of the Census (1960), series D-735, adjusted so that the data refer to U.S. members of unions on the basis of the U.S. proportion of labor union membership in 1930 in series D-741 and D-742. This eliminates Canada members of U.S. unions. For the period 1880 to 1913 I used the series of union membership reported by Gerald Friedman (1995), spliced to BLS-series (itself adjusted to be on a CPS comparable basis) at the overlap year 1914.

The nonagricultural employment series are derived from several sources as well. For 1966 to 1995, I used the Economic Report of the President, table B-42; for 1930 to1965 I used 
the data in U.S. Department of Commerce 1966, series A-88. For the years 1900 to 1929 I used the data in the U.S. Department of Commerce, series A-87. For 1889 to 1899 I used series A70 from the same volume; those data are an index of manhours in nonagricultural industires, and I applied the index numbers to the 1900 nonagricultural employment data in series A-87. Finally, as there are no annual nonagricultural employment series prior to 1989 , I estimated employment by assuming it grew proportionate to population, as reported in series A-106. 
Appendix A, Table 1: New Estimates of Union Membership and Union Density in the United States, 1880-1995

\begin{tabular}{|c|c|c|c|}
\hline Year & $\begin{array}{r}\text { Estimated } \\
\text { Membership } \\
(000)\end{array}$ & $\begin{array}{r}\text { Nonagricultural } \\
\text { Employment } \\
(000)\end{array}$ & $\begin{array}{r}\text { Union Density } \\
\text { (Percent) }\end{array}$ \\
\hline 1880 & 149 & 9,284 & 1.61 \\
\hline 1881 & 167 & 9,520 & 1.76 \\
\hline 1882 & 253 & 9,757 & 2.59 \\
\hline 1883 & 278 & 9,993 & 2.79 \\
\hline 1884 & 343 & 10,229 & 3.36 \\
\hline 1885 & 427 & 10,465 & 4.08 \\
\hline 1886 & 1,060 & 10,702 & 9.90 \\
\hline 1887 & 828 & 10,938 & 7.57 \\
\hline 1888 & 612 & 11,174 & 5.48 \\
\hline 1889 & 627 & 11,411 & 5.49 \\
\hline 1890 & 722 & 11,980 & 6.03 \\
\hline 1891 & 753 & 12,386 & 6.08 \\
\hline 1892 & 697 & 12,956 & 5.38 \\
\hline 1893 & 703 & 12,684 & 5.55 \\
\hline 1894 & 762 & 11,926 & 6.39 \\
\hline 1895 & 614 & 13,010 & 4.72 \\
\hline 1896 & 539 & 12,956 & 4.16 \\
\hline
\end{tabular}




\begin{tabular}{|c|c|c|c|}
\hline Year & $\begin{array}{r}\text { Estimated } \\
\text { Membership } \\
(000)\end{array}$ & $\begin{array}{r}\text { Nonagricultural } \\
\text { Employment } \\
(000)\end{array}$ & $\begin{array}{r}\text { Union Density } \\
\text { (Percent) }\end{array}$ \\
\hline 1897 & 544 & 13,498 & 4.03 \\
\hline 1898 & 624 & 13,552 & 4.60 \\
\hline 1899 & 730 & 14,988 & 4.87 \\
\hline 1900 & 1,028 & 15,178 & 6.78 \\
\hline 1901 & 1,265 & 16,294 & 7.77 \\
\hline 1902 & 1,477 & 17,395 & 8.49 \\
\hline 1903 & 1,982 & 17,858 & 11.10 \\
\hline 1904 & 2,094 & 17,640 & 11.87 \\
\hline 1905 & 2,001 & 18,707 & 10.70 \\
\hline 1906 & 1,895 & 20,069 & 9.44 \\
\hline 1907 & 2,021 & 20,523 & 9.85 \\
\hline 1908 & 2,000 & 19,259 & 10.38 \\
\hline 1909 & 1,895 & 21,203 & 8.94 \\
\hline 1910 & 1,993 & 21,697 & 9.18 \\
\hline 1911 & 2,153 & 22,093 & 9.75 \\
\hline 1912 & 2,213 & 23,191 & 9.54 \\
\hline 1913 & 2,436 & 24,143 & 10.09 \\
\hline 1914 & 2,393 & 23,190 & 10.32 \\
\hline 1915 & 2,315 & 23,149 & 10.00 \\
\hline
\end{tabular}




\begin{tabular}{|c|c|c|c|}
\hline Year & $\begin{array}{r}\text { Estimated } \\
\text { Membership } \\
(000)\end{array}$ & $\begin{array}{r}\text { Nonagricultural } \\
\text { Employment } \\
(000)\end{array}$ & $\begin{array}{r}\text { Union Density } \\
\text { (Percent) }\end{array}$ \\
\hline 1916 & 2,461 & 25,510 & 9.65 \\
\hline 1917 & 2,691 & 25,802 & 10.43 \\
\hline 1918 & 3,045 & 26,432 & 11.52 \\
\hline 1919 & 3,658 & 27,270 & 13.41 \\
\hline 1920 & 4,551 & 27,434 & 16.59 \\
\hline 1921 & 4,269 & 24,542 & 17.40 \\
\hline 1922 & 3,571 & 26,616 & 13.42 \\
\hline 1923 & 3,281 & 29,231 & 11.22 \\
\hline 1924 & 3,209 & 28,577 & 11.23 \\
\hline 1925 & 3,224 & 29,751 & 10.84 \\
\hline 1926 & 3,248 & 30,599 & 10.61 \\
\hline 1927 & 3,255 & 30,481 & 10.68 \\
\hline 1928 & 3,225 & 30,539 & 10.56 \\
\hline 1929 & 3,277 & 31,339 & 10.46 \\
\hline 1930 & 3,284 & 29,424 & 11.16 \\
\hline 1931 & 3,196 & 26,649 & 11.99 \\
\hline 1932 & 2,945 & 23,628 & 12.46 \\
\hline 1933 & 2,596 & 23,711 & 10.95 \\
\hline 1934 & 2,982 & 25,953 & 11.49 \\
\hline
\end{tabular}




\begin{tabular}{|c|c|c|c|}
\hline Year & $\begin{array}{r}\text { Estimated } \\
\text { Membership } \\
(000)\end{array}$ & $\begin{array}{r}\text { Nonagricultural } \\
\text { Employment } \\
(000)\end{array}$ & $\begin{array}{r}\text { Union Density } \\
\text { (Percent) }\end{array}$ \\
\hline 1935 & 3,460 & 27,053 & 12.79 \\
\hline 1936 & 3,851 & 29,082 & 13.24 \\
\hline 1937 & 6,760 & 31,026 & 21.79 \\
\hline 1938 & 7,757 & 29,209 & 26.56 \\
\hline 1939 & 8,461 & 30,618 & 27.63 \\
\hline 1940 & 8,416 & 32,376 & 26.00 \\
\hline 1941 & 9,849 & 36,554 & 26.94 \\
\hline 1942 & 10,022 & 40,125 & 24.98 \\
\hline 1943 & 12,757 & 42,452 & 30.05 \\
\hline 1944 & 13,658 & 41,883 & 32.61 \\
\hline 1945 & 13,828 & 40,394 & 34.23 \\
\hline 1946 & 13,899 & 41,674 & 33.35 \\
\hline 1947 & 14,277 & 43,881 & 32.54 \\
\hline 1948 & 13,825 & 44,891 & 30.80 \\
\hline 1949 & 13,790 & 43,778 & 31.50 \\
\hline 1950 & 13,775 & 45,222 & 30.46 \\
\hline 1951 & 14,962 & 47,849 & 31.27 \\
\hline 1952 & 15,344 & 48,825 & 31.43 \\
\hline 1953 & 16,364 & 50,232 & 32.58 \\
\hline
\end{tabular}




\begin{tabular}{|c|c|c|c|}
\hline Year & $\begin{array}{r}\text { Estimated } \\
\text { Membership } \\
(000)\end{array}$ & $\begin{array}{r}\text { Nonagricultural } \\
\text { Employment } \\
(000)\end{array}$ & $\begin{array}{r}\text { Union Density } \\
\text { (Percent) }\end{array}$ \\
\hline 1954 & 16,435 & 49,022 & 33.53 \\
\hline 1955 & 16,223 & 50,675 & 32.01 \\
\hline 1956 & 16,887 & 52,408 & 32.22 \\
\hline 1957 & 16,770 & 52,894 & 31.71 \\
\hline 1958 & 16,442 & 51,368 & 32.01 \\
\hline 1959 & 16,527 & 53,297 & 31.01 \\
\hline 1960 & 16,461 & 54,203 & 30.37 \\
\hline 1961 & 15,741 & 53,989 & 29.16 \\
\hline 1962 & 16,014 & 55,515 & 28.85 \\
\hline 1963 & 15,954 & 56,602 & 28.19 \\
\hline 1964 & 16,260 & 58,156 & 27.96 \\
\hline 1965 & 16,703 & 60,444 & 27.63 \\
\hline 1966 & 17,322 & 63,901 & 27.11 \\
\hline 1967 & 17,734 & 65,803 & 26.95 \\
\hline 1968 & 18,264 & 67,897 & 26.90 \\
\hline 1969 & 18,380 & 70,384 & 26.11 \\
\hline 1970 & 18,713 & 70,880 & 26.40 \\
\hline 1971 & 18,549 & 71,211 & 26.05 \\
\hline 1972 & 18,765 & 73,675 & 25.47 \\
\hline
\end{tabular}




\begin{tabular}{|c|c|c|c|}
\hline Year & $\begin{array}{r}\text { Estimated } \\
\text { Membership } \\
(000)\end{array}$ & $\begin{array}{r}\text { Nonagricultural } \\
\text { Employment } \\
(000)\end{array}$ & $\begin{array}{r}\text { Union Density } \\
\text { (Percent) }\end{array}$ \\
\hline 1973 & 19,167 & 76,790 & 24.96 \\
\hline 1974 & 19,503 & 78,265 & 24.92 \\
\hline 1975 & 18,935 & 76,945 & 24.61 \\
\hline 1976 & 18,957 & 79,382 & 23.88 \\
\hline 1977 & 19,016 & 82,471 & 23.06 \\
\hline 1978 & 19,548 & 86,697 & 22.55 \\
\hline 1979 & 20,986 & 89,823 & 23.36 \\
\hline 1980 & 20,095 & 90,406 & 22.23 \\
\hline 1981 & 19,507 & 91,152 & 21.40 \\
\hline 1982 & 18,558 & 89,544 & 20.73 \\
\hline 1983 & 17,717 & 90,152 & 19.65 \\
\hline 1984 & 17,340 & 94,408 & 18.37 \\
\hline 1985 & 16,996 & 97,387 & 17.45 \\
\hline 1986 & 16,975 & 99,344 & 17.09 \\
\hline 1987 & 16,913 & 101,958 & 16.59 \\
\hline 1988 & 17,002 & 105,210 & 16.16 \\
\hline 1989 & 16,961 & 107,895 & 15.72 \\
\hline 1990 & 16,740 & 109,419 & 15.30 \\
\hline 1991 & 16,568 & 108,256 & 15.30 \\
\hline
\end{tabular}




\begin{tabular}{rrrr} 
Year & $\begin{array}{r}\text { Estimated } \\
\text { Membership } \\
(000)\end{array}$ & $\begin{array}{r}\text { Nonagricultural } \\
\text { Employment } \\
(000)\end{array}$ & $\begin{array}{r}\text { Union Density } \\
\text { (Percent) }\end{array}$ \\
\hline 1992 & 16,390 & 108,604 & 15.09 \\
1993 & 16,598 & 110,730 & 14.99 \\
1994 & 16,740 & 114,034 & 14.68 \\
1995 & 16,360 & 116,609 & 14.03
\end{tabular}




\section{Endnotes}

1. In the simple case where $O R G=a U_{N I O N_{-1}}-b\left[U_{N I O N_{-1}}\right]^{2}$ and where OPP $=b-$ c UNION ${ }_{-1}$, the difference equation is a second order one.

2. The timing of the legal changes deserves some attention. In May 26, 1933, the NIRA was passed. The first code, with a statement on unionization, was given in July. In 1934 Roosevelt ordered the Labor Board to conduct bargaining elections and they held 528 elections with approximately 30,000 votes. In May 27, 1935, the Supreme Court declared the NIRA unconstitutional in the Schechter Poultry Co. decision. The Congress passed the Wagner Act on July 27, 1935. The Act was upheld by the U.S. Supreme Court in National Labor Relations Board v. Jones and Laughlin (April, 1937). 